\title{
The Purposes and Functions of Exclusionary Rules: A Comparative Overview
}

\author{
Jenia Iontcheva Turner and Thomas Weigend
}

\begin{abstract}
The chapter analyzes the rationales for excluding relevant evidence with the aim of establishing the ideal type of exclusion system for each rationale. The authors then review to what extent individual legal systems have actually altered their legal rules in accordance with these ideal systems. An investigation into whether or not there are any consistent relationships between the ideal systems and proclaimed rationales is conducted. The structure of various exclusionary rules is also explored, as are other factors that may influence the law and practical application of such rules.
\end{abstract}

\section{Introduction}

The exclusion of relevant evidence from the trial interferes with one of the main goals of the criminal process, that is, the determination of all relevant facts ("the truth") as the basis of the verdict. For that reason, many criminal justice systems, both adversarial and inquisitorial, have long viewed rules demanding the exclusion of relevant evidence ("exclusionary rules") as an obstacle to the search for truth and therefore have greatly limited their application. Over the course of the twentieth century, however, the use of exclusionary rules has increased significantly. More

Portions of Jenia Turner's contributions to this chapter draw on her previous work in Turner, 2016; Turner, 2014.

J. I. Turner $(\bowtie)$

SMU Dedman School of Law, Dallas, USA

e-mail: Jenia@mail.smu.edu

T. Weigend

Faculty of Law, University of Cologne, Cologne, Germany

e-mail: Thomas.Weigend@uni-koeln.de

(C) The Author(s) 2019

S. Gless and T. Richter (eds.), Do Exclusionary Rules Ensure a Fair Trial?

Ius Gentium: Comparative Perspectives on Law and Justice 74,

https://doi.org/10.1007/978-3-030-12520-2_8 
and more legal systems decided to use exclusion of evidence as a reaction to violations of rules concerning the acquisition of evidence. ${ }^{1}$

In adversarial systems, exclusion can be based on the logic that a party which obtains a piece of evidence illegally should not be allowed to benefit from the fruits of the violation. In inquisitorial systems, it is more difficult to rely on this rationale of exclusion because evidence is regarded as "belonging" to the court, not to one of the parties. Still, there are overriding concerns that may justify a court's decision to exclude a piece of evidence. Such concerns can be related to systemic interests (e.g., the appearance of fairness) or individual interests (e.g., vindication of the rights of the individual affected by the violation). Each of these interests may be so important as to outweigh the procedural interest in having the full range of relevant evidence available at the trial.

Every legal system recognizes exclusionary rules as a reaction to particularly serious violations. There is an almost universal rule that statements made as a result of torture must not be used in court. ${ }^{2}$ But beyond this common core, the breadth and contents of exclusionary rules differ widely. In some jurisdictions, the law generally prohibits the admission of any evidence obtained illegally. ${ }^{3}$ Other states are more reticent and recognize only a limited number of "absolute" exclusionary rules, leaving exclusion in other cases to the discretion of the court, or permitting the admission of illegally obtained evidence if the interest in making use of it for "finding the truth" outweighs the taint of its illegal acquisition.

At the same time, legal systems differ with respect to the purposes they proclaim to pursue by excluding illegally obtained evidence. In some systems, the integrity of fact-finding or of the judicial system as such is the most prominent concern that supports the exclusion of evidence. In other systems, deterrence of police misconduct is foremost. In yet others, the principal justification for exclusion rests on the protection of individual rights. The general tendency toward protecting human rights that has prevailed in the last few decades has given a boost to such considerations.

In this chapter, we will start out by analyzing the potential rationales for excluding relevant evidence (Sect. 2) and will then attempt to construe ideal types of exclusion systems based on each rationale (Sect. 3). We will then review to what extent individual legal systems have actually devised their legal rules in accordance with these ideal types (Sect. 4). By way of conclusion, we will ask whether there is any consistent relationship between the ideal types based on the proclaimed

\footnotetext{
${ }^{1}$ This chapter focuses on illegally obtained evidence and therefore does not discuss rules that some legal systems use to exclude evidence in order to "absolutely" protect specific interests, e.g., the core of the right to privacy, even in the absence of police misconduct.

${ }^{2}$ Art. 15 UN Convention against Torture (1984) ("Each State Party shall ensure that any statement which is established to have been made as a result of torture shall not be invoked as evidence in any proceedings, except against a person accused of torture as evidence that the statement was made.").

${ }^{3}$ Greece is an example of such an absolutist approach to exclusion. See Giannoulopoulos, 2007, p. 181.
} 
rationales and the actual configuration of exclusionary rules, and what other factors may in fact influence the law and practice of excluding evidence (Sect. 5).

\section{Rationales of Exclusionary Rules}

In this chapter, we review the most common rationales used to support the exclusion of unlawfully obtained evidence. We will first deal with system-related considerations, such as promoting the search for truth and the integrity of the criminal justice system. We will then examine deterrence of police misconduct and protection of individual rights as justifications for excluding evidence.

\subsection{Finding the Truth}

In order to properly fulfil its functions, any procedural system, regardless of whether it is party-oriented or court-centered, must meet certain basic requirements: A functional procedural system needs to present courts as principally fair and oriented toward a just disposition of cases in accordance with the law; this includes an orientation of fact-finding toward the "truth", or more realistically, a renunciation of court decisions based on evident fiction. Courts are encouraged to pursue these basic goals through admitting and taking into consideration any evidence that appears to be factually relevant for the disposition of the case.

Yet in exceptional situations, the introduction of individual pieces of evidence may fatally undermine the integrity of the proceedings. For example, basing a conviction on a confession that the defendant made under torture not only conflicts with the ideal of judicial integrity but also raises doubts as to the court's truth-orientation, because torture tends to make the victim say anything that he thinks will put an end to the pain. Evidence may therefore be excluded if the methods used to obtain it have rendered it unreliable. ${ }^{4}$ This rationale applies to the suppression of verbal statements obtained as a result of torture or, in some cases, deceit of the person questioned or the inability to confront key witnesses. ${ }^{5}$

The reliability-based rationale has a limited area of application, however. It rarely comes into play with regard to physical evidence. When drugs are seized illegally or a telephone conversation is taped without a necessary judicial warrant, the unlawful government action does not in any way reduce these items' probative value. Therefore, excluding such evidence would undermine the search for truth instead of advancing it.

\footnotetext{
${ }^{4}$ Jackson/Summers, 2012, at 154.

${ }^{5}$ Macula, 2019 at 3; $R$ v. Grant [2009] 2 SCR 353, 110 (Can.); Chalmers v. H.M. Advocate 1954 JC 66, 83 (Scot.); Israel Supreme Court, Yissacharov v. Chief Military Prosecutor, Judgment of 4 May 2006, CrimA 5121/98, § 71 (Justice Beinisch); Strafprozessordnung (Ger.) § 136a.
} 


\subsection{Upholding Judicial Integrity}

A broader justification for the exclusion of illegally obtained evidence is the preservation of the integrity of the judicial system. ${ }^{6}$ This rationale assumes that courts would taint their own reputation and dignity if they (routinely) base their decisions on evidence that has been obtained through gross violations of the law. Courts should therefore exclude tainted evidence in order to demonstrate to the public that they do not condone illegal acts of government agents and that they refuse to base their decisions on the results of such acts. By declining to become "accomplices in the willful disobedience of [the law] they are sworn to uphold"7 and by renouncing the use of illegally obtained evidence, courts reaffirm the rule of law and buttress the legitimacy of criminal proceedings. ${ }^{8}$

To the extent the integrity rationale emphasizes the integrity of the individual judicial process, it tends to support robust, categorical approaches to exclusion. But in another variant of this rationale, also known as "systemic integrity," the focus is more broadly on "not bringing the administration of justice into disrepute." 9 This version of the integrity rationale recognizes that while exclusionary rules may contribute to the propriety of the criminal process, they can also undermine the acceptance of the criminal justice system if they lead to the non-prosecution or

\footnotetext{
${ }^{6}$ See, e.g., ECtHR, Gäfgen v. Germany, case no. 22978/05, Judgment (Grand Chamber) of 1 June $2010, \S 175$ ("Indeed, there is also a vital public interest in preserving the integrity of the judicial process and thus the values of civilised societies founded upon the rule of law."). Like other courts and writers, the ECtHR here refers not only to "the integrity of the judicial process" but also to the "rule of law." The latter is a very basic value of any judicial system. However, exclusion of evidence does not specifically promote the "rule of law," because the law can provide for different ways of dealing with illegally obtained evidence. By contrast, "the integrity of the judicial process" (or, for short, "judicial integrity") describes the specific interest potentially violated by admitting tainted evidence.

${ }^{7}$ Elkins v. United States, 364 US 206, 223 (1960); see also Israel Supreme Court, Yissacharov v. Chief Military Prosecutor, Judgment of 4 May 2006, CrimA 5121/98 (Justice Beinisch), § 45 ("[T] he administration of justice is also based on the way in which the court reaches its decision in the circumstances of the case before it. Basing a conviction on evidence that was obtained in an illegal manner or by means of a substantial violation of a protected human right allows the investigation authorities to enjoy the fruits of their misdeed and it may create an incentive for improper acts of interrogation in the future. Admitting such evidence may be seen as the court giving approval to the aforesaid illegality and being an accessory, albeit after the event, to the improper conduct of the investigation authorities. Consequently, in certain circumstances admitting the evidence in court may prejudice the fairness and integrity of the judicial process.").

${ }^{8}$ This rationale has been particularly influential in countries emerging from authoritarian regimes and transitioning to liberal democracy. In those countries, the exclusionary rule has been valued for curtailing government abuse and for affirming that even government officials are subject to legal restraints. See Turner, 2014.

${ }^{9}$ Canadian Charter of Rights and Freedoms, Part I of the Constitutional Act, 1982, being Schedule B to the Canada Act, 1982, c. 24 (U.K.) ("[T]he evidence shall be excluded if it is established that, having regard to all the circumstances, the admission of it in the proceedings would bring the administration of justice into disrepute.”); $R$ v. Grant [2009] 2 SCR 353, §§ 68-70 (Can.).
} 
acquittal of persons who are most likely to be guilty of serious crime. The public may lose faith in the proper functioning of the system if courts frequently exclude reliable evidence and consequently fail to convict because crucial evidence is then missing.

The systemic integrity approach therefore favors a balancing of factors reflecting these competing interests. On the one hand, courts should examine the seriousness of the official misconduct, including the culpability of the officers, the presence of a pattern of misconduct, and the significance of the right violated; on the other hand, to determine the costs of exclusion, courts should consider the gravity of the offense charged, the reliability of the evidence, and the centrality of the evidence to the case against the defendant. ${ }^{10}$

\subsection{Deterring Police Misconduct}

One aspect of promoting the integrity of the criminal process concerns the influence that exclusion of evidence may have on police conduct. In the great majority of procedural systems, most investigation work is performed by police officers, and it is often they who break the rules concerning the acquisition of evidence. The integrity aspect of criminal procedure is therefore most vulnerable on the police level. ${ }^{11}$ Accordingly, one function of excluding illegally obtained evidence is to dissuade law enforcement officers from violating the law. ${ }^{12}$

Exclusion for "deterrence" purposes is based on the assumption that police officers, even if they are not at all times focused on respecting procedural safeguards, have a strong professional interest in seeing offenders convicted. By excluding evidence that the officer had acquired in violation of the law and thereby dramatically reducing the odds of conviction, courts hope to nudge police officers toward complying with the law in the future. It is not by chance that the notion of excluding evidence for the purpose of deterring unlawful police conduct has played a great role in the United States, following revelations of grave and systematic police violations of suspects' rights in the U.S. legal system in the 1960s. ${ }^{13}$ Exclusion of evidence obtained through the use of illegal police methods was seen as an indispensable means for re-establishing the integrity and public acceptance of the criminal justice system.

\footnotetext{
${ }^{10}$ See Slobogin, 2016 at 287-291.

${ }^{11}$ In Spano v. New York, 360 US 315, 320 (1959), the U.S. Supreme Court explained its new emphasis on police illegality used to obtain the confession (rather than on the inherent untrustworthiness of coerced confessions): "[t]he abhorrence of society to the use of involuntary confessions does not turn alone on their inherent untrustworthiness. It also turns on the deep-rooted feeling that the police must obey the law while enforcing the law."

${ }^{12}$ United States v. Leon, 468 US 897, 918 (1984); Hudson v. Michigan, 547 US 586, 591 (2006); Herring v. United States, 555 US 135 (2009).

${ }^{13}$ Miller/Wright, 2007 at 521-522 (discussing the findings of the Wickersham Commission).
} 
More recently, however, the U.S. Supreme Court has concluded that the social costs of exclusion may outweigh the benefits of deterrence. ${ }^{14}$ As part of this cost-benefit analysis, the Court has taken into account the availability of alternative sanctions that may be able to discipline officers at a lesser cost to the administration of justice. ${ }^{15}$ It has further limited the applicability of the deterrence rationale by declaring that deterrence can operate only where police officers violate procedural rules deliberately or recklessly. ${ }^{16}$

Although prominent in the United States, the deterrence approach has not gained much of a following elsewhere. To the extent deterrence of police misconduct is mentioned by European courts, it is typically used as a secondary consideration supporting other purposes of exclusion. ${ }^{17}$ In Germany, a few authors have recognized deterrence of police misconduct as one purpose of excluding illegally obtained evidence ${ }^{18}$; but the majority have rejected that approach, arguing that this rationale does not fit the inquisitorial structure of the German criminal process and would interfere too much with the courts' mandate to search for the truth. ${ }^{19}$

The skepticism toward the idea of deterring police misconduct by excluding evidence from trial may be well-founded. There exists at best a tenuous psychological connection between excluding evidence of past misconduct and preventing future ones: the mechanism of "deterrence" can function only if: (a) offending police officers are informed of the forensic fate of the individual criminal process, and (b) they care about that fate. The empirical foundations of either precondition is doubtful, however. ${ }^{20}$ Especially if police use torture or other unlawful means for purposes other than obtaining evidence to be used in criminal proceedings (e.g., because they wish to humiliate members of an ethnic group or because they are looking for information unrelated to criminal proceedings), the fact that statements obtained through their acts are inadmissible at trial will have little influence on their behavior.

\footnotetext{
${ }^{14}$ United States v. Leon, 468 US 897, 907 (1984); Hudson v. Michigan, 547 US 586, 591, 599 (2006); Herring v. United States, 555 US 135, 141 (2009).

${ }^{15}$ Hudson v. Michigan, 547 US 586, 591, 599 (2006).

${ }^{16}$ Herring v. United States, 555 US 135, 144 (2009).

${ }^{17}$ See, e.g., Macula, 2019 at 3.1.1.

${ }^{18}$ See Grünwald, 1966 at 499-500; Spendel, 1966 at 1104-1105.

${ }^{19}$ Küpper, 1990 at 417; Jäger, 2003 at $69-71$.

${ }^{20}$ Alschuler, 2008 at 1374 (reviewing U.S. studies of the exclusionary rule's deterrence effect and concluding that while the exclusionary rule does not have a direct and immediate deterrent effect on officers' behavior, it "works over the long term by allowing judges to give guidance to police officers who ultimately prove willing to receive it").
} 


\subsection{Human Rights Considerations}

An alternative approach to justifying the exclusion of relevant evidence aims at the protection of human rights. ${ }^{21}$ Exclusion, according to this rationale, is to provide the victims of human rights violations with an effective remedy. This rationale has been influential in several of the countries studied in this volume, including Germany, Switzerland, and Taiwan. The U.S. Supreme Court followed this approach in some of its earlier opinions on the exclusionary rule, explaining that without exclusion, provisions that protect fundamental rights would be reduced to "a form of words" 22 and would not have any meaningful legal effect. ${ }^{23}$ Yet, the US Supreme Court has since abandoned this rationale and has switched to an emphasis on deterrence of police misconduct. ${ }^{24}$

Regional human rights courts, by contrast, have in recent years begun to prod states to provide for exclusion of evidence obtained through human rights violations. Human rights law requires states to ensure the protection of, inter alia, the right to a fair trial, ${ }^{25}$ the right to be free from arbitrary searches and seizures, ${ }^{26}$ the right to privacy, ${ }^{27}$ and the right not to be compelled to testify against oneself. ${ }^{28}$ The domestic implementation of provisions protecting human rights has made states aware of the need to adopt mechanisms that can effectively safeguard these rights. Human rights courts tend to leave questions of the admissibility of evidence to individual states and do not generally require that evidence be excluded if gathered in violation of one of these rights. ${ }^{29}$ But they mandate exclusion of statements obtained through serious violations of fair trial such as entrapment of innocent citizens to commit crimes, ${ }^{30}$ torture or degrading treatment, ${ }^{31}$ and in the Inter-American human rights regime, even of statements obtained through lesser

\footnotetext{
${ }^{21}$ Israel Supreme Court, Yissacharov v. Chief Military Prosecutor, Judgment of 4 May 2006, CrimA 5121/98 (Justice Beinisch), § 61; Ashworth, 1977; Jackson/Summers, 2012, at 155.

${ }^{22}$ Silverthorne Lumber Co. v. United States, 251 US 385, 392 (1920).

${ }^{23}$ Weeks v. United States, 232 US 383, 393 (1914).

${ }^{24} I d$.

${ }^{25}$ ICCPR art. 14(1); ECHR art. 6.

${ }^{26}$ ICCPR art. 17; ECHR art. 8.

${ }^{27}$ ICCPR art. 17; ECHR art. 8.

${ }^{28}$ ICCPR art. 14(3); ECHR art. 8.

${ }^{29}$ See, e.g., ECtHR, Khan v. United Kingdom, case no. 35394/97, Judgment of 12 May 2000, (31 Eur. Ct. H.R. 45), § 34 .

${ }^{30}$ See, e.g., ECtHR, Furcht v. Germany, case no. 54648/09, Judgment of 23 October 2014, §§ 62-64.

${ }^{31}$ ECtHR, Gäfgen v. Germany, case no. 22978/05, Judgment (Grand Chamber) of 1 June 2010, $\S \S$ 166-168; see UN Convention Against Torture and Other Cruel, Inhuman or Degrading Treatment or Punishment, art. 15.
} 
forms of coercion. ${ }^{32}$ Human rights law has thus, directly as well as indirectly, contributed to the expansion of exclusionary rules designed to protect human rights.

However, the functional relationship between the exclusion of evidence and the protection of human rights is less than clear. One can conceive of exclusion as a mechanism for preventing future human rights violations; exclusion is to demonstrate to potential violators that it is not worthwhile to use torture or other prohibited methods because evidence obtained thereby will not be admissible in court. This is the logic of deterrence of police misconduct, which we have mentioned above (Sect. 2.3). But it is an open question whether (and why) the criminal justice system should be obliged to contribute to a better protection of human rights. Exclusion may have an indirect positive effect on reducing human rights violations, but its undeniable direct effect is a reduction of the factual basis on which the court's verdict can be based. It is thus the criminal justice system that has to pay the price for the possible improvement in human rights protection.

The main argument in favor of exclusion from a human rights perspective is, however, not systemic but individualistic: inadmissibility is to provide the victim of the violation with some kind of compensation. This argument, however, suffers from several flaws. First, compensation of this kind is provided only for a relatively small portion of victims of human rights violations, i.e., those who are subsequently subjected to a criminal trial. Second, exclusion can apply only if the human rights violation produced evidence relevant to a criminal case. Third, exclusion of evidence may give little satisfaction to the victim of a serious violation if the piece of evidence in question is of little significance to the outcome of the case and its exclusion does not preclude conviction. ${ }^{33}$ In sum, exclusion of evidence affects only a very small, fortuitously composed portion of victims of human rights violations, and even for that group, its compensatory effect is dubious.

On the other hand, acquittal of a serious offender may be over-compensation for a minor violation of his procedural rights. For example, if an officer conducts a car search based on a good faith belief that she has sufficient cause to do so, but a court later disagrees and excludes a murder weapon seized in the search, so that the defendant is acquitted for lack of evidence, acquittal may be seen as an out-of-proportion reaction to the invasion of the defendant's privacy. And even if exclusion is not disproportionate-should the "criminal" go free because the constable has blundered? The fact that a police officer violated a defendant's rights does not in any way reduce the defendant's blameworthiness for the act he committed; and although he should be compensated for the violation of his rights, the exclusion of relevant evidence lacks an inherent nexus with the injury the defendant suffered.

\footnotetext{
${ }^{32}$ American Convention on Human Rights, art. 8(3) ("A confession of guilt by the accused shall be valid only if it is made without coercion of any kind.").

${ }^{33}$ For example, an intrusive bodily search of a suspect conducted by police without probable cause and without a warrant may produce evidence of drug-dealing (i.e., the drugs themselves) that is relevant but not crucial to the case against the suspect; its exclusion would hardly compensate the victim of the illegal search for the harm done to him.
} 
The compensation rationale for the exclusion of evidence is, in sum, less than convincing. It might be useful, on the basis of the above considerations, to limit exclusion to instances in which the production of evidence in court would itself violate a person's human rights. This would be the case, for example, if the transcript of an illegally taped telephone conversation between the defendant and his wife would be read in open court, because disclosing this conversation to the public would be a new violation of the couple's right to marital intimacy. By contrast, the introduction of drugs discovered in the defendant's car through an illegal warrantless search would not, by itself, violate the defendant's human rights.

\section{Ideal Types of Exclusionary Systems}

In this section, we briefly sketch possible consequences of a system's decision to opt for one of the key exclusionary rule rationales discussed above: systemic integrity, deterrence, or protecting human rights. We do this by constructing ideal types of exclusionary regimes, that is, by postulating consequences from their underlying purposes without taking into account the individual factual and normative conditions and limitations of any specific legal system. In defining the ideal types, we cannot deal with all details and possible ramifications of exclusionary regimes; we will therefore focus on several key doctrinal questions that have the potential of differentiating between systems and also have significant practical effect. In this regard, we will highlight five aspects of the application of exclusionary rules: (a) whether there is a strict exclusionary rule or whether it is subject to balancing; (b) whether the decision to exclude depends on the specific right that has been violated; (c) whether the officer's good faith precludes exclusion; (d) whether evidence indirectly derived from the original violation is excluded; and (e) whether exclusion can be invoked by persons whose rights were not directly violated.

\subsection{Ideal Type "System Integrity"}

\subsubsection{Balancing Interests}

If the purpose behind excluding illegally obtained evidence is to preserve or restore the integrity of the judicial system, declaring inadmissible any evidence acquired in violation of a procedural rule might be counterproductive because exclusion itself can jeopardize the (perceived) integrity of the judicial process by leading to verdicts based on fiction rather than truth. Balancing between the interest in basing the judgment on the totality of available relevant evidence and disregarding items of evidence whose use would "shock the conscience" seems to be the optimal approach under this rationale. 


\subsubsection{Type of Right Violated}

If the integrity of the criminal justice system is the purpose of exclusion, the type of right violated (e.g., privacy, bodily integrity, secrecy of telecommunications) should not play a decisive role, because all individual rights protected by applicable international or domestic law are part of the system and require equal respect. For the purpose of balancing, it is therefore irrelevant which individual right has been compromised $^{34}$; it is only the intensity and scope of the violation that needs to be considered in the weighing process. Although the right to freedom and the right to bodily integrity both deserve protection under the "integrity" approach, a statement made by the defendant at the police station is more likely to be excluded if he was tortured than if police detained him for an hour longer than was permissible under the applicable law.

If, however, the finding of the "truth" is regarded as an important systemic interest, it matters whether the violation is likely to affect the reliability of the evidence in question. Accordingly, evidence derived from torture or coercion should be excluded, whereas violations of other important rights, such as the right to the privacy of telecommunication, should not necessarily lead to suppression.

Even if the type of right violated should not matter in a system promoting integrity, it can be argued that the sanction need not always be exclusion, but could instead vary based on the seriousness of the violation.

\subsubsection{Good Faith Exception}

The systemic integrity approach weighs the social costs of exclusion and demands exclusion only where the gravity of the violation outweighs the costs. If a law enforcement officer committed a procedural fault in good faith, for example, because he relied on a statute or a judicial decision later found to be unconstitutional, or on an innocent misconception of the relevant facts, the evidence obtained may be the result of a malfunctioning of the legal system as a whole, but the individual officer in question cannot be blamed with having violated the law. There is thus a lesser taint on the evidence in question, which should weigh in favor of admission especially if the evidence is needed in order to arrive at a factually correct judgment. The legal system might be expected to favor exclusion, however, if the misconduct is due to negligence. For example, where one officer relies on the actions of another officer, court administrator, or judge, a "system integrity" approach might base exclusion of evidence on the fact that at least one government agent acted against the law. If the officer knew that he violated the law or was reckless as to the legality of his acts, this fact shows a grave defect in the operation

\footnotetext{
${ }^{34}$ One might consider affording human dignity a special status; but given the vague contours of human dignity, a rule of absolute exclusion whenever human dignity had been infringed may lead to inappropriate results.
} 
of the criminal justice system and should be a strong argument for exclusion. ${ }^{35}$ For less serious breaches, courts following the systemic integrity approach might impose less drastic remedies, such as declaratory relief or sentence discounts after conviction. ${ }^{36}$ For example, Dutch law provides several different remedies for violations of individual rights by government officials, ranging from a mere declaration of illegality to a sentence reduction and exclusion of the evidence. ${ }^{37}$

\subsubsection{Exclusion of Derivative Evidence}

The exclusion of evidence derived from results of an illegal investigatory act ("fruit of the poisoned tree") is ambivalent under the "integrity" rationale. On the one hand, one can argue that the evidence in question (e.g., drugs discovered as a result of an interrogation conducted without proper warnings) is not tainted by the illicit path that led to its discovery; therefore, admission of the item-which is of undiminished probative value - does not conflict with the ethical integrity of the system. Under an approach focusing on reliability, admitting evidence that was indirectly derived from the original violation also makes sense. Such derivative evidence is generally unlikely to be rendered less reliable on account of a preceding violation. ${ }^{38}$

On the other hand, it cannot be denied that the origin of the chain that leads to the acquisition of a piece of evidence can be so abhorrent that a system geared toward integrity should refrain from using it - for example, if the suspect had disclosed the place where drugs were hidden only after having been brutally tortured. A legal system that places great emphasis on the rule of law would therefore be inclined to exclude derivative evidence at least in cases of serious violations. A sensible solution to this dilemma may be to resort to balancing the interests involved: there should not be an absolute rule of admission or of exclusion, but the "taint" on the individual item of evidence stemming from the origin of its discovery should be weighed against its relevance for a just outcome of the process.

\footnotetext{
${ }^{35}$ See, e.g., Evidence Act 1995 (Cth) s 138(3) (Austl.); Evidence Act 2006, § 30(3) (N.Z.); $R$ v. Grant [2009] 2 SCR. 353, §§ 73-75 (Can.); $R$ v. Canale [1990] 91 Cr. App. R. 1 (Eng.); Israel Supreme Court, Yissacharov v. Chief Military Prosecutor, Judgment of 4 May 2006, CrimA 5121/ 98, § 62 (Justice Beinisch).

${ }^{36}$ See, e.g., $R$ v. Nasogaluak [2007] 229 CCC (3d) 52 (Alta. C.A.); Butler/Butler, 2005 at $1037 \S$ 29.6.5.

${ }^{37}$ Borgers/StevensLonneke in Thaman, 2013 at 183, 190.

${ }^{38} \mathrm{An}$ exception to this presumption would be a second confession following an initial coerced confession. Studies of wrongful convictions have shown that, once a person has given a false confession under pressure from the police, the coercive influence of the first confession might lead to a second false confession, even when police are no longer applying deceptive or coercive tactics.
} 


\subsubsection{Standing of Persons Other Than the Victim of the Violation}

If exclusion of evidence is designed to maintain the integrity of the judicial system, anybody should be entitled to raise the issue of exclusion. This means that a defendant should be able to demand exclusion even if only the rights of another person had allegedly been violated when the evidence was obtained. For example, a defendant would be able to claim that the search of a witness's home was illegal and that therefore contraband found in the home should not be introduced as evidence at the defendant's trial. Moreover, it would be consistent with this approach that the court could (and indeed, should) exclude illegally obtained evidence on its own motion, even if none of the parties requests exclusion.

\subsubsection{Summary}

A system justifying exclusion of evidence by the interest of maintaining the integrity of the judicial process would have these features: The interest in excluding illegally obtained evidence is weighed against the interest in having a complete array of relevant evidence available for the judgment. ${ }^{39}$ There is hence no absolute rule of exclusion; the degree of the violation and the importance of the individual rights affected are parts of the balancing process, and so is the question of whether the item in question has been directly or indirectly obtained through an illegal method. Questions of standing do not play a role in the decision on exclusion: any participant in the trial (and indeed, the court) can trigger an examination of possible exclusion by claiming that a piece of evidence was obtained illegally.

\subsection{Ideal Type "Deterrence"}

\subsubsection{Balancing Interests}

If deterrence is the principal goal of exclusion, a categorical approach toward exclusion seems warranted. Deterrence will work only if law enforcement personnel are certain that their investigative efforts will be in vain if they resort to forbidden methods.

On the other hand, a judicial system may balance the interest in deterrence against other procedural interests, such as that of establishing the truth and of enforcing the criminal law, thereby carving out different categories of illegal conduct. If deterrence outweighs competing considerations (for example, in instances

\footnotetext{
${ }^{39}$ If the focus is on promoting the rule of law in systems that have recently moved to liberal democracy, perhaps there is a greater need for categorical rules because of concerns that a "balanced" exclusionary rule would be toothless.
} 
of systemic or deliberate misconduct), evidence will invariably be excluded. If, on the other hand, deterrence benefits are marginal while social costs are significant (for example, where the officer has relied in good faith on an illegal warrant issued by a magistrate), evidence will be admitted.

\subsubsection{Type of Right Violated}

Under a deterrence approach, the type of right violated should not affect the decision whether to exclude evidence. The focus in this model is on encouraging police officers to abide by the law, not on the effect that the misconduct has on the individual. On the other hand, one could argue that if an officer is violating only a minor administrative regulation, deterrence is of lesser importance and exclusion of evidence would be an over-reaction. Other than in such extreme cases, however, courts focused on deterrence ought not to differentiate as to the type of the right that had been violated.

\subsubsection{Good Faith Exception}

How the deterrence model should view "good faith" violations of the law is a matter of continued debate. The dominant view is that if an officer has acted in "good faith," there is no room for deterrence. For example, if the officer relied on a statute or a judicial decision later found to be unconstitutional or on an innocent misconception of the relevant facts, he cannot be blamed for having violated the law, and there is no conduct from which he needs to be deterred. The need to "punish" a police officer for misconduct is therefore absent or at least strongly reduced if he acted without fault or was only slightly negligent in the course of investigating the crime. ${ }^{40}$ If, on the other hand, the officer violated the law deliberately or recklessly, this is the type of misconduct that merits exclusion of the evidence, because the officer is to learn to abide by the legal norm in the future. ${ }^{41}$

Some scholars have contested this narrow view of deterrence as being too focused on individual officers rather than on police departments as a whole. $^{42}$ Commentators have further argued that negligent mistakes can and should be deterred and that exclusion therefore should not be limited to reckless or deliberate

\footnotetext{
${ }^{40}$ United States v. Leon, 468 US 897 (1984); Illinois v. Krull, 480 US 340, 347 (1987); Arizona v. Evans, 514 US 1, 11 (1995); Herring v. United States, 555 US 135, 141 (2009).

${ }^{41}$ See, e.g., Evidence Act 1995 (Cth) s 138(3) (Austl.); Evidence Act 2006, § 30(3) (N.Z.); $R$ v. Grant [2009] 2 SCR 353, §§ 73-75 (Can.); $R$ v. Canale (1990) 91 Cr. App. R. 1 (Eng.); Israel Supreme Court, Yissacharov v. Chief Military Prosecutor, Judgment of 4 May 2006, CrimA 5121/ 98, § 62 (Justice Beinisch).

${ }^{42}$ Levine et al., 2016.
} 
misconduct. ${ }^{43}$ Under this view, the threat of exclusion would provide an incentive for police departments to conduct better training to minimize even negligent errors.

\subsubsection{Exclusion of Derivative Evidence}

Exclusion of derivative evidence should be favored under the deterrence paradigm, because police officers might be encouraged to employ forbidden methods if they know that derivative evidence can later be used in order to convict the suspect. If, however, the link between the violation and the evidence at issue is strongly attenuated, exclusion may not be warranted for deterring similar violations. For example, if the police arrest someone unlawfully, the person is subsequently released, and then returns to the police station to make a voluntary confession, this statement may be too distant from the unlawful arrest to warrant exclusion ${ }^{44}$ : An officer in a similar situation would not expect that a person would voluntarily return to make a confession, and therefore is not likely to be deterred from misconduct by exclusion of the confession.

\subsubsection{Standing of Persons Other Than the Victim of the Violation}

If exclusion of evidence is designed to deter misconduct, anybody should be entitled to raise the issue of exclusion, just as under the judicial integrity approach.

\subsubsection{Summary}

A deterrence-based approach to the exclusion of evidence would have a relatively strict and categorical approach to exclusion in order to provide clear guidance to officers and minimize the likelihood of misconduct. The type of right violated and the question whether the item in question was directly or indirectly obtained through an illegal method would generally not be central to the question of exclusion, while the offending officer's culpability and the systemic nature of the misconduct would be. To maximize deterrence of misconduct, any participant in the trial should have standing to demand exclusion, even if his or her rights were not directly violated by the action that led to the acquisition of the evidence.

\footnotetext{
${ }^{43}$ See, e.g., Lafave, 2009 at 768-70.

${ }^{44}$ Wong Sun v. United States, 371 US 471 (1963).
} 


\subsection{Ideal Type "Vindication of Individual Rights"}

\subsubsection{Balancing Interests}

In a human rights centered ideal type, exclusion of evidence is a logical and unavoidable consequence of the violation of a procedural rule protecting the individual. There is no balancing against procedural interests; to the extent such interests are taken into consideration, they remain external to the rationale of exclusion. The only "internal" limit to exclusion would be its waiver by the affected individual: If the defendant does not object to the introduction of the tainted evidence, there is no reason for excluding it.

\subsubsection{Type of Right Violated}

Under this rationale, exclusion should ensue only if an individual right has been affected; a violation of general interests of the procedural system (e.g., the illegal exclusion of the public from the trial, or the unlawful disclosure of state secrets) cannot lead to the exclusion of relevant evidence. One could consider gradating human rights and attaching exclusion only to the violation of those rights deemed particularly important. But the admission of evidence obtained in violation of any human right protected by international law or domestic constitutional law would be difficult to reconcile with this rationale.

\subsubsection{Good Faith Exception}

From a human rights perspective, it makes little difference whether the officer conducting an unlawful search or interfering with a person's core privacy acted in good faith. What counts is the unlawful intrusion by a state agent into the protected sphere of an individual. A "good faith" exception would thus not be compatible with a human rights rationale.

\subsubsection{Exclusion of Derivative Evidence}

If exclusion of evidence is to reinstate the victim of a human rights violation to his or her prior status and to deprive the state of the fruits of the violation of human rights, exclusion should extend to the "fruits of the poisonous tree." Evidence derived from information obtained by a human rights violation thus should not be admitted if there exists a clear and direct causal connection between the violation and the acquisition of the evidence. 


\subsubsection{Standing of Persons Other Than the Victim of the Violation}

Although rules on standing can be informed by various procedural considerations, the logic of the human rights rationale suggests limiting standing to the individual affected by the violation (or his survivors if he was killed).

\subsubsection{Summary}

In summary, the ideal type of an exclusion system based on a human rights rationale has these key features: Exclusion of evidence is an invariable consequence of any violation of an individual human right. Exclusion extends to violations that occurred unintentionally and also to evidence indirectly derived from the original violation. Only the individual affected has standing to demand exclusion; he or she may also waive exclusion, which is binding on the court.

\section{Choice of Rationale and Its Consequences}

Do real world systems reflect the ideal types described above? Can we detect any doctrinal patterns based on the rationale adopted? Legal systems do not tend to subscribe unconditionally to the ideal types as described here. In fact, many jurisdictions ground their exclusionary rules on more than one rationale. The mix of rationales - which the law often fails to spell out clearly-makes it difficult to predict the actual scope of exclusionary rules in any given legal system. Even where one rationale is dominant, courts and scholars often seek to accommodate subsidiary rationales as well. They may do so expressly by adopting a balancing test, or indirectly by carving out exceptions to categorical rules. In this section, we examine to what extent selected legal systems rely on one of the doctrinal bases identified above, and how that choice is reflected in the actual features of exclusion of illegally obtained evidence. For that purpose, we group legal systems along the three ideal types identified above, i.e., "system integrity," "deterrence," and "human rights," and then examine whether their choice of rationale bears on their position concerning the distinctive issues treated above (Sect. 3). 


\subsection{Legal Systems Based on the "System Integrity" Rationale}

Canada and Israel are examples of legal systems that ground their exclusionary rule on a systemic integrity analysis. ${ }^{45}$ Consistent with expectations, both systems apply a multi-factor, balancing test in deciding whether to exclude unlawfully obtained evidence. Empirical studies of rates of exclusion, however, suggest that the Canadian balancing test is more robust and more likely to produce exclusion than the Israeli approach.

Differentiation among various rights occurs in both Canada and Israel. Although the Canadian Supreme Court has abandoned a previous distinction between "conscripted" and "non-conscripted" evidence (under which courts were more likely to suppress evidence where the accused had been "compelled to participate in the creation or discovery of the evidence"), ${ }^{46}$ courts still take the nature of the right violated into account when assessing the impact of police misconduct on the interests of the accused. ${ }^{47}$ As the Canadian Supreme Court elaborated in Grant, "[t]he more serious the impact on the accused's interests, the greater the risk that admission of the evidence may signal to the public that Charter rights, however high-sounding, are of little actual avail to the citizen, breeding public cynicism and bringing the administration of justice into disrepute." ${ }^{48}$ To determine the seriousness of the breach, Canadian courts look to the right violated: Thus "[a]n unreasonable search that intrudes on an area in which the individual reasonably enjoys a high expectation of privacy, or that demeans his or her dignity, is more serious than one that does not. ${ }^{, 49}$ In Israel, courts likewise consider the type of right violated in deciding whether the breach is sufficiently serious to outweigh truth-seeking concerns. As the Israeli Supreme Court explained in a seminal case on the exclusionary rule, "[l]ogic dictates that a technical, negligible or inconsequential violation of the rules of proper investigation is not the same as a serious breach of these rules involving a significant violation of one of the main basic rights of the person under investigation." $" 50$

Both Canadian and Israeli courts, as expected, take the good faith of the individual police officer into consideration when deciding on the exclusion of evidence. As the Israeli Supreme Court noted, "When the investigation authorities have intentionally violated the provisions of law that bind them or they have knowingly

\footnotetext{
${ }^{45} R$ v. Grant [2009] SCC 32; Israel Supreme Court, Yissacharov v. Chief Military Prosecutor, Judgment of 4 May 2006, CrimA 5121/98, $\S \S 47,68$ (Justice Beinisch).

${ }^{46}$ Stuart, 2010 at 324.

${ }^{47} R$ v. Grant [2009] SCC 32, § 76; $R$ v. Harris [2007] ONCA 574, § 63; R. v. Bacchus [2012] ONSC 5082, $\S \S 90-93$.

${ }^{48} R$ v. Grant [2009] SCC 32, § 76.

${ }^{49} I d . \S 78$.

${ }^{50}$ Israel Supreme Court, Yissacharov v. Chief Military Prosecutor, Judgment of 4 May 2006, CrimA 5121/98, § 70 (Justice Beinisch).
} 
violated a protected right of the person under investigation, this is capable of increasing the seriousness of the violation of the rules of proper investigation and the possible violation of due process if the evidence is admitted in the trial. Conduct that involves an intentional violation on the part of the investigation authorities may, therefore, be a circumstance of considerable weight for declaring the evidence inadmissible even when the defect is not serious." ${ }^{, 1}$ In deciding how serious a breach is and what its effects are on systemic integrity, Canadian courts likewise consider it relevant to determine whether officers acted deliberately or recklessly, or conversely, in good faith. ${ }^{52}$

It is worth noting, however, that while culpability of the officers is relevant, good faith does not automatically make the resulting evidence admissible in either Canada or Israel. ${ }^{53}$ As the Israeli Supreme Court explained, "for example, in circumstances where the defect that occurred in the manner of obtaining the evidence was serious and involved a substantial violation of the protected rights of the person under investigation, then the mere fact that the authority acted in good faith will not prevent the evidence being excluded."

Canadian courts recognize the "fruit of the poisonous tree" doctrine, but limit it in situations where the evidence would have been obtained even if the violation had not occurred. ${ }^{55}$ In Israel, by contrast, the courts have entirely rejected the doctrine. ${ }^{56}$

With regard to the issue of standing, the Canadian Supreme Court has held that an accused may invoke the exclusionary rule only if the police misconduct affected his personal right. ${ }^{57}$ Commentators have argued that this limitation of exclusion is more consistent with a compensatory, individual rights based approach, rather than the systemic integrity approach espoused by Canadian courts. ${ }^{58}$

\footnotetext{
${ }^{51} I d . \S 70$.

${ }^{52} R$ v. Grant [2009] 2 SCR 353, $\S ~ 75,214$ (Can.); Stuart, 2010 at 314, 318; Porter/Kettles, 2012.

${ }^{53} R$ v. Grant [2009] 2 SCR 353, $\$ 75$ (Can.) ("[I]gnorance of [constitutional] standards must not be rewarded or encouraged and negligence or wilful blindness cannot be equated with good faith."); $R$ v. Wilson [2003] CarswellOnt 9051 (citing unnamed case in which trial judge excluded evidence where officer relied on an invalid warrant in good faith); $R$ v. $R$ (J.F.R.) [1991] YJ No. 235 (Can. Yukon Terr. Ct.) (excluding evidence in a case of negligent police violation of the law).

${ }^{54}$ Israel Supreme Court, Yissacharov v. Chief Military Prosecutor, Judgment of 4 May 2006, CrimA 5121/98, § 70 (Justice Beinisch).

${ }^{55} R$ v. Grant [2009] 2 SCR 235 (Can.). Interestingly, the Canadian Court argued that the admission of evidence that would have been inevitably discovered has a lesser impact on the rights of the accused - a position criticized by some Canadian scholars; see Stuart, 2010 at 330.

${ }^{56}$ See, e.g., Israel Supreme Court, Yissacharov v. Chief Military Prosecutor, Judgment of 4 May 2006, CrimA 5121/98, \& 71 (Justice Beinisch) (leaving exclusion of derivative evidence to case-by-case determination).

${ }^{57} R$ v. Edwards [1996] 1 SCR 128; see also $R$ v. Pasian [2015] ONSC 1557.

${ }^{58}$ See, e.g., Paciocco, 2011 at 32 ("If the repute of the administration of justice is indeed harmed by the admission of evidence it must be so whether or not the person whose rights have been violated complains. And if an objective is to vindicate Charter rights generally and not in the individual case it makes no sense for the framers of s. 24(2) to have linked the operation of the remedy to an application by the party whose rights have been violated.").
} 
This short overview of two systems that both rely on an integrity approach to exclusion shows some similarities but also suggests that the same approach can yield different doctrinal paths. On some of the doctrinal touchstones, the two systems are in harmony and in line with our expectations, but in other regards both of them depart from the model of system integrity outlined above.

\subsection{Legal Systems Based on the "Deterrence" Rationale}

In the United States, the exclusionary rule is based on a deterrence-oriented analysis. Consistent with the expectation of the model, the U.S. approach is relatively rule-bound and categorical, at least when compared with the more flexible balancing used in other jurisdictions. ${ }^{59}$ If the police violate the Constitution, the exclusionary rule is presumed to apply, unless the prosecution can rely on a specific exception.

On the other hand, the U.S. Supreme Court has in recent years applied a cost-benefit analysis, weighing the deterrence benefits of exclusion against its social costs. This approach has led to the recognition of an increasing number of exceptions to the exclusionary rule ${ }^{60}$ and is moving the U.S. away from a purely deterrence-oriented model toward the system integrity approach discussed in the previous section.

Concerning the possible differentiation among various rights, the U.S. Supreme Court has not expressly acknowledged a differential treatment based on the right violated, yet its jurisprudence shows that mandatory exclusion is more likely to apply to coerced confessions, unlawful searches of a home, and particularly invasive body searches. By contrast, a cost-benefit analysis is more likely to result in admitting the tainted evidence when violations of seemingly less important rightssuch as violations of the "prophylactic" Miranda regime - have occurred. ${ }^{61}$ This gradation is not fully consistent with a purist deterrence model, which would generally not distinguish among rights violated.

The U.S. Supreme Court, following the narrow version of the deterrence approach, has taken the good faith of individual police officers into consideration when deciding on the exclusion of evidence. In Herring v. United States, the majority opinion explained:

$[P]$ olice conduct must be sufficiently deliberate that exclusion can meaningfully deter it, and sufficiently culpable that such deterrence is worth the price paid by the justice system. As laid out in our cases, the exclusionary rule serves to deter deliberate, reckless, or grossly negligent conduct, or in some circumstances recurring or systemic negligence. ${ }^{62}$

\footnotetext{
${ }^{59}$ See Levine et al., 2016.

${ }^{60}$ See, e.g., Herring v. United States, 555 US 135 (2009).

${ }^{61}$ Turner, 2019.

${ }^{62}$ Herring v. United States, 555 US 135, 144 (2009).
} 
The Court has therefore rejected arguments that exclusion can be used more broadly to encourage police departments to adopt more rigorous training programs that help prevent even negligent mistakes by police officers. ${ }^{63}$

In line with its emphasis on deterring police misconduct, the U.S. Supreme Court has traditionally extended exclusion to "evidence obtained from or as a consequence of lawless official acts." ${ }^{" 64}$ Yet the Court has gradually narrowed the fruit of the poisonous tree doctrine, recognizing the competing interests at stake. For example, it has approved the admission of derivative evidence if the connection between the original violation and the evidence in question has been attenuated (e.g., if an event has broken the chain of causation between the original illegality and the derivative evidence). ${ }^{65}$ The Court also declared derivative evidence admissible if the police would inevitably have discovered it in the course of its investigation. The Court justified these limitations on the exclusionary rule by pointing to the high costs of excluding probative evidence and the limited deterrent effect of excluding evidence that either has been or would have been discovered independently by lawful means. ${ }^{66}$

With regard to the issue of standing, the United States Supreme Court has limited the right to invoke the exclusionary rule to individuals directly harmed by the misconduct. ${ }^{67}$ This limitation cannot be easily squared with the Court's emphasis on deterrence. Yet the Court has refrained from extending standing to third parties, even in cases where it was clear that police intentionally conducted an unconstitutional search of a person who would not have standing in a criminal case to move for suppression of the evidence. ${ }^{68}$

The Supreme Court justified its narrow approach to standing by citing the significant costs of excluding evidence:

Each time the exclusionary rule is applied it exacts a substantial social cost for the vindication of Fourth Amendment rights. Relevant and reliable evidence is kept from the trier of fact and the search for truth at trial is deflected [...]. Since our cases generally have held that one whose Fourth Amendment rights are violated may successfully suppress evidence obtained in the course of an illegal search and seizure, misgivings as to the benefit of enlarging the class of persons who may invoke that rule are properly considered when deciding whether to expand standing to assert Fourth Amendment violations. ${ }^{69}$

\footnotetext{
${ }^{63} I d$. at 173-174 (Ginsburg, J., dissenting).

${ }^{64}$ See Costello v. United States, 365 US 265, 280 (1961).

${ }^{65}$ Brown v. Illinois, 422 US 590, 603-604 (1975); Murray v. United States, 487 US 533, 537 (1988).

66"If the prosecution can establish by a preponderance of the evidence that the information ultimately or inevitably would have been discovered by lawful means - here the volunteers' search - then the deterrence rationale has so little basis that the evidence should be received. The requirement that the prosecution must prove the absence of bad faith ... wholly fails to take into account the enormous societal cost of excluding truth in the search for truth in the administration of justice." Nix v. Williams, 467 US 431, 444-445 (1984).

${ }^{67}$ Rakas v. Illinois, 439 US 128, 137-138 (1978); Fisher v. United States, 425 US 391, 397-398 (1976).

${ }^{68}$ United States v. Payner, 447 US 727 (1980).

${ }^{69}$ Rakas v. Illinois, 439 US 128, 137-138 (1978).
} 
In this context, the Court seems to be mixing rationales, weighing the goal of truth-seeking, on the one hand, against the goal of deterring misconduct. We thus see that, like Canada and Israel, the United States is another example of a system that in practice departs in several respects from the exclusionary model it purports to follow.

\subsection{Legal Systems Based on the Human Rights Rationale}

Greece is an example of a legal system regarding exclusion of evidence as a means of vindicating fundamental individual rights. ${ }^{70}$ Article $177 \S 2$ of the Greek Code of Criminal Procedure provides that evidence obtained through a criminal act must not be used in court, except in favor of the accused. More specifically, Article $19 \S 3$ of the Greek Constitution in its 2001 version strictly prohibits the use of evidence obtained through a violation of the secrecy of letters and telecommunication (Art. $19 \S 1$ Const.), a person's home or private life (Art. $9 \S 1$ Const.), or the protection of personal data (Art. 9A $\S 1$ Const.). The courts have extended the application of this article to other serious violations of constitutional provisions, such as the use of torture in violation of Art. $7 \S 2$ of the Constitution. ${ }^{71}$ The prohibition of "using" such illegally obtained evidence applies to: (1) all stages of criminal proceedings; (2) direct and derivative evidence; (3) evidence obtained by private actors and evidence obtained by state officials; and (4) cases in which a third party's rights, not the defendant's, were violated. The remarkable breadth of exclusion in Greece has been linked in part to the "bitter, and not-too-distant, experience of rule by military junta" and in part to the emphasis on fundamental rights. ${ }^{72}$

Although the Greek system comes close to the ideal type of a human rights based system, it does not fit the model in all respects. For example, courts have fashioned broad standing rules that allow third parties to invoke the exclusionary rule. ${ }^{73}$ Under a strict individual-rights perspective, this is surprising (see Sects. 3.1.5, 3.2.5 and 3.3.5). But perhaps the broad Greek rule can be explained by the fact that Greece aims at making sure that no evidence based on human rights violations will be accepted by the courts, even when this may overcompensate individual litigants in some cases.

Furthermore, Greek courts have occasionally strayed from the broad rights-based approach to exclusion. With respect to unlawful wiretaps, for example, the Greek Supreme Court has held that they "may be used as evidence when they are the only means for proving innocence, or even guilt, in the case of a very serious crime." 74

\footnotetext{
${ }^{70}$ Giannoulopoulos, 2007 at 192, 207-208; see also Kaissis, 2015 at 461-462.

${ }^{71}$ Spyropoulos/Fortsakis, 2009 at 229.

${ }^{72}$ Giannoulopoulos, 2007 at 208.

${ }^{73} \mathrm{Id}$. at 207.

${ }^{74}$ Triantafyllou, 2013 at 275.
} 
In departing from the otherwise strict constitutional exclusionary rule, the court stressed the need for a balance between conflicting interests in the criminal process. $^{75}$

Another example of a rights-based approach to exclusion is that of Ireland-at least, it was until 2015. Irish courts until recently justified exclusion based on the courts' duty: "to protect persons against the invasion of their constitutional rights; (ii) if invasion has occurred, to restore as far as possible the person so damaged to the position in which he would be if his rights had not been invaded." ${ }^{, 76}$ Consistent with an approach based on vindicating individual rights, Irish courts used "one of the strictest exclusionary rules" in the world: "Where evidence is obtained in breach of the constitutional rights of a suspect it is subject to automatic exclusion at trial, unless there are in existence extraordinary excusing circumstances justifying its admission." ${ }^{, 77}$ The exclusionary rule applied to inadvertent as well as deliberate violations of the law, and it extended to evidence derived from the original breach. ${ }^{78}$ The Irish Supreme Court had rejected a good faith exception to the exclusionary rule on the ground of the "unambiguously expressed constitutional obligation as "far as practicable to defend and vindicate the personal rights of the citizen." "79

Yet after criticism of the broad Irish exclusionary rule by a number of judges and policymakers, the Irish Supreme Court in 2015 drastically reduced its scope, holding that an inadvertent breach of the law in the gathering of evidence would not lead to exclusion. ${ }^{80}$ The new rule departs from the rights-based rationale of exclusion and appears to introduce a balancing approach more concerned with judicial integrity. ${ }^{81}$

The Greek and Irish systems of exclusion suggest that even seemingly absolute, rights-oriented approaches to exclusion at times give way to exceptions or balancing tests. ${ }^{82}$ As the next section elaborates, the mixing of rationales is perhaps the most common approach to exclusion in practice.

\footnotetext{
${ }^{75} I d$.

${ }^{76}$ Trimbole v. Governor of Mountjoy Prison [1985] IR 550, 573.

${ }^{77}$ Daly, 2011 at 199; Director of Public Prosecutions v. JC [2015] IESC 31, 95 (noting that the previous rule called for "near absolute exclusion" and was "the most extreme" in the common law world).

${ }^{78}$ Director of Public Prosecutions v. JC [2015] IESC 31, § 95.

${ }^{79}$ Director of Public Prosecutions v. Kenny [1990] 2 IR 110, 134 (Ir.); Thaman, 2010 at 352.

${ }^{80}$ Director of Public Prosecutions v. JC [2015] IESC 31.

${ }^{81} I d$. at $\S 97$ ("When does the admission of that evidence itself bring the administration of justice in to disrepute? This analysis leads inevitably to a more nuanced position which would admit evidence by reason of a technical and excusable breach, but would exclude it where it was obtained as a result of a deliberate breach of the Constitution."); Leon/Ward, 2015 at 593.

${ }^{82}$ Slobogin, 2016 at 291 (reviewing countries that follow the rights vindication model and finding that they undermine the rule-as-vindication rationale in various ways).
} 


\subsection{Mixed Systems}

Several legal systems have refrained from defining a single rationale for their exclusionary rules. Three of the countries discussed in this volume-Switzerland, Germany, and Taiwan - are examples of such hybrid systems.

The German and Swiss models have been grounded on the need to vindicate individual rights as well as to protect the rule of law. In Taiwan, the judiciary introduced an exclusionary rule in 1998, which was subsequently codified by the legislature as part of a broader effort to break with the legacy of a decade-long authoritarian regime. The rule "came about at a time that the new government was distancing itself from the previous government's perceived abuse of power .... [T] he post-martial-law government made a definitive statement that 'we are not them." "83

The rationale for the Taiwanese exclusionary rules is to protect individual rights and safeguard the rule of law and judicial integrity. ${ }^{84}$ While some specific exclusionary rules - for example, concerning confessions obtained through torture - are categorical and result in mandatory exclusion, others are flexible and applied on the basis of a balancing approach. The balancing takes into account a host of factors, but ultimately aims to weigh the protection of individual rights against the public interest in the enforcement of criminal law. ${ }^{85}$

The German and Swiss approaches to exclusion similarly follow a dual approach, with some rules, such as those pertaining to coerced confessions, resulting in mandatory exclusion, while others balance the public interest and individual rights. ${ }^{86}$

These systems share a tendency toward categorically excluding evidence if certain very important rights have been violated. ${ }^{87}$ For example, statements obtained through torture are mandatorily excluded in most systems studied, and so are results of violations of a core sphere of privacy. On the other hand, physical evidence obtained through unlawful searches or seizures is less likely to be excluded; and the same is true with respect to violations of "administrative" or "technical" rules. ${ }^{88}$

Many "mixed" systems take the culpability of the officer into account when deciding on admissibility of evidence. In Taiwan, for example, one factor in the balancing analysis is "the subjective intentions of the official, i.e., whether the

\footnotetext{
${ }^{83}$ Lewis, 2011 at 648 ; see also Chen, 2011 at $719-720$ (noting that the Taiwanese judiciary adopted the exclusionary rule in an effort to assert its independence and to gain legitimacy by protecting human rights).

${ }^{84}$ Lin et al., 2019 at 1.

${ }^{85}$ Lin et al., 2019.

${ }^{86}$ Macula, 2019.

${ }^{87}$ See Thaman, 2013 at 416-417 (discussing exclusionary rules in Spain, Colombia, Brazil, Portugal, Greece, and Germany); Macula, 2019; Lin et al., 2019.

${ }^{88}$ See, e.g., Macula, 2019.
} 
official knows his conduct is unlawful., ${ }^{89}$ German courts are also more likely to exclude evidence where officers have purposefully or recklessly violated the law. ${ }^{90}$ A similar inquiry into the officer's motivation and state of mind occurs with respect to indirect evidence in Spain. ${ }^{91}$ It is possible that the consideration of the officer's state of mind in these systems is a nod to a subsidiary, competing rationale - to deter police misconduct or to safeguard the integrity of the criminal justice system.

We find a mixed pattern of solutions with regard to the "fruits of the poisonous tree" doctrine. In Taiwan, courts extend the exclusionary rule to derivative evidence $^{92}$ although "evidence acquired by an independent legitimate investigation shall not be supressed." 93 Spanish, ${ }^{94}$ German, ${ }^{95}$ and Swiss ${ }^{96}$ courts recognize the doctrine in a limited fashion. Spanish courts use a balancing test to determine whether to exclude evidence indirectly derived from a breach, and the officer's state of mind in committing the breach is an important factor. ${ }^{97}$ In Switzerland and Germany, the fruit of the poisonous tree doctrine is used for some violations, but the courts recognize a "hypothetical clean path" exception, which is interpreted quite broadly. $^{98}$

With regard to standing, Germany pursues a strict approach, insisting that only the person whose rights were violated can invoke the exclusionary rule. For example, the Federal Court of Justice ruled that a defendant cannot demand the exclusion of the incriminating statement of a witness who had not been informed of his privilege against self-incrimination when interrogated by the police. ${ }^{99}$

\footnotetext{
${ }^{89}$ Lin et al., 2019 at 3.1.3.

${ }^{90}$ Bundesgerichtshof [BGH] [Federal Court of Justice] Judgment of 18 April 2007, 51 Entscheidungen des Bundesgerichtshofes in Strafsachen 285, 2007 (Ger.) (upholding exclusion where the police "intentionally circumvented the protective warrant requirement"); Bundesverfassungsgericht [Federal Constitutional Court], Judgment of 9 November 2011, [2011] Neue Juristische Wochenschrift 2417 (Ger.) (stating that evidence would be excluded "if there has been a grave, conscious, or arbitrary violation of procedural law which infringed upon the protection of an individual's fundamental rights in a planned or systematic fashion"). One of us has noted a trend toward exclusion in recent German decisions, "especially where important individual rights have been violated and the law enforcement officer acted without good faith."; Weigend, 2015 at 195.

${ }^{91}$ Bachmaier Winter, 2013 at 216-217.

${ }^{92}$ Lin et al., 2019 at 3.2.6.

${ }^{93}$ Lin et al., 2019 at 3.2.6.2 (quoting Supreme Court decision 102 taishangzih No. 4177 (最高法院 102年度台上字第 4177 號判決)).

${ }^{94}$ Bachmaier Winter, 2013 at 232.

${ }^{95}$ Gless, 2013 at 128.

${ }^{96}$ Macula, 2019.

${ }^{97}$ Bachmaier Winter, 2013 at 232.

${ }^{98}$ Macula 2019; Weigend, 2019 (in this volume) German report at notes 98 et seq.

${ }^{99}$ BGH, Decision of 21 January 1958 - GSSt 4/57 (11 Entscheidungen des Bundesgerichtshofes in Strafsachen 213, 215).
} 


\section{Conclusion: Aligning Doctrines with Rationales?}

Looking at our findings from a comparative standpoint, the rationales that different systems rely upon do not fall into an expected pattern. No clear divide exists between adversarial and inquisitorial systems. A trend we do identify, however, is that for most systems, particularly those that have adopted exclusionary rules relatively recently, the dominant rationales for exclusionary rules are to protect individual rights and promote judicial integrity rather than to deter misconduct or promote the search for truth. This development can probably be attributed to the growing influence of international human rights law and to an emphasis on the rule of law in countries transitioning away from authoritarian regimes.

Not surprisingly, we have not encountered a legal system that exactly mirrors one of the ideal types construed in section 3. To begin with, virtually all the countries we examined pursue more than one goal when excluding evidence, even if one objective may be dominant; and the majority of systems rely on a mix of rationales to support their exclusionary rules.

But even where a legal system expresses a pronounced orientation toward a "human rights" or a "deterrence" rationale, such as Greece and the United States, respectively, the choice of rationale does not necessarily seem to determine the resolution of the key issues we have identified. Of course, quite a few of our findings comport with the ideal-typical models. The emphasis on protecting individual rights has led countries such as Greece, Ireland, and Russia to adopt - at least on paper-broad and categorical exclusionary rules; and "hybrid" systems such as Germany and Switzerland have embraced a broad balancing approach designed to make it possible to find compromise between conflicting interests in each case. Contrary to expectations, however, the United States-although oriented toward deterring police misconduct-limits standing to persons directly affected by the violation that led to the evidence, whereas Greece - although professing adherence to a "human rights" rationale - grants standing to individuals who were not personally affected by the human rights violation in question. On the other hand, adopting the same rationale does not necessarily lead to identical doctrines of exclusion, as can be seen from the examples of Israel and Canada. Instead, one and the same rationale can justify a variety of approaches to exclusion, from balancing to categorical exclusion and from relatively narrow to relatively broad rules.

These variations can easily be explained by the fact that even legal systems which emphasize a single basic rationale for exclusion reasonably take other considerations and interests into account when shaping rules on individual issues. Certain overriding considerations appear to influence exclusionary decision-making to a larger extent than adherence to basic rationales. For example, legal systems are most likely to use absolute exclusionary rules with respect to violations of certain fundamental rights, such as the right not to be subjected to torture. When rationales coincide, and especially when the truth-seeking rationale weighs on the side of exclusion, legal systems are most likely to exclude evidence. 
Policy considerations can also be expected to have a great influence on the design of actual exclusionary rules. For example, legal systems that regard police misconduct as a serious problem — such as the United States in the 1960s and 1970s - can be expected to establish broad exclusionary rules but to limit them to bad-faith disregard of citizens' procedural rights; systems which have faith in police to obey the legal rules will see less need to shape their exclusionary rules in order to achieve deterrence.

In sum, we can say that a strict doctrinal adherence to particular rationales and purposes of exclusion of evidence plays a lesser role in the construction and application of exclusionary rules when compared to considerations of fairness, procedural expediency, and an interest in keeping a balance between the truth-orientation and the rights-orientation of the criminal process. The official purposes of excluding evidence are of course welcome arguments for supporting individual sub-rules and court decisions; but they are not determinative. Judges who shape and apply legal rules in difficult areas do not simply apply doctrines but take real life and basic notions of fairness into account. And that is probably how it should be.

\section{References}

\section{Books}

Butler, Andrew/Butler, Petra, The New Zealand Bill of Rights Act: A Commentary, Wellington NZ 2005. [Butler/Butler, 2005]

Jackson, John D./Summers, Sarah J., The Internationalisation of Criminal Evidence: Beyond the Common Law and Civil Law Traditions, Cambridge 2012. [Jackson/Summers, 2012]

Jäger, Christian, Beweisverwertung und Beweisverwertungsverbote im Strafprozess, Munich 2003. [Jäger, 2003]

Miller, Marc L./Wright, Ronald F., Criminal Procedures: The Police, New York 2007. [Miller/ Wright, 2007]

Spyropoulos, Philippos/Fortsakis, Theodore P., Constitutional Law in Greece, Dordrecht 2009. [Spyropoulos/Fortsakis, 2009]

\section{Journal Articles}

Alschuler, Albert W., 'Studying the Exclusionary Rule: An Empirical Classic', (2008) 75 University of Chicago Law Review, 1365-1384. [Alschuler, 2008]

Ashworth, Andrew, 'Excluding Evidence as Protecting Rights', (1977) 3 Criminal Law Review, 723-735. [Ashworth, 1977]

Chen, Yu-Jie, 'One Problem, Two Paths: A Taiwanese Perspective on the Exclusionary Rule in China', (2011) 43 NYU Journal of International Law and Politics 713-728. [Chen, 2011]

Daly, Yvonne Marie, 'Judicial Oversight of Policing: Investigations, Evidence and the Exclusionary Rule', (2011) 55 Crime, Law and Social Change, 199-215. [Daly, 2011] 
Giannoulopoulos, Dimitrios, 'The Exclusion of Improperly Obtained Evidence in Greece: Putting Constitutional Rights First', (2007) 11 International Journal of Evidence and Proof 181-212. [Giannoulopoulos, 2007]

Gless, Safine, 'Germany: Balancing Truth Against Protected Institutional Interests', (2013) 20 IUS Gentium, 113-142. [Gless, 2013]

Grünwald, Armin, 'Beweisverbote und Verwertungsverbote im Strafverfahren', (1966) 21 Juristenzeitung, 489-501. [Grünwald, 1966]

Kaissis, Athanassios, 'Exclusion of Illegally Obtained Evidence in Greek Civil and Criminal Proceeding-An Outline', (2015) 2 Digesta OnLine Law Review, 453-463. [Kaissis, 2015]

Küpper, Georg, 'Tagebücher, Tonbänder, Telefonate', (1990) 45 Juristenzeitung, 416-424. [Küpper, 1990]

Lafave, Wayne R., 'The Smell of Herring: A Critique of the Supreme Court's Latest Assault on the Exclusionary Rule', (2009) 99 Journal of Criminal Law and Criminology, 757-788. [Lafave, 2009]

Leon, Clare/Ward, Tony, 'The Irish Exclusionary Rule After DPP v JC', (2015) 35 Legal Studies, 590-593. [Leon/Ward, 2015]

Levine, Kay, et al., 'Evidence Laundering in a Post-Herring World', (2016) 106 Journal of Criminal Law and Criminology, 627-680. [Levine et al., 2016]

Lewis, Margaret K., 'Controlling Abuse To Maintain Control: The Exclusionary Rule in China', (2011) 43 NYU Journal of International Law and Politics, 629-697. [Lewis, 2011]

Paciocco, David M., 'Section 24(2): Lottery or Law-The Appreciable Limits of Purposive Reasoning', (2011) 58 Criminal Law Quarterly, 15-66. [Paciocco, 2011]

Spendel, Günter, 'Beweisverbote im Strafprozess', (1966) 19 Neue Juristische Wochenschrift, 1102-1108. [Spendel, 1966]

Stuart, Don, 'Welcome Flexibility and Better Criteria from the Supreme Court of Canada for Exclusion of Evidence Obtained in Violation of the Canadian Charter of Rights and Freedoms', (2010) 16 Southwestern Journal of International Law, 313-332. [Stuart, 2010]

Thaman, Stephen C., 'Fruits of the Poisonous Tree" in Comparative Law', (2010) 16 Southwestern Journal of International Law 333-384. [Thaman, 2010]

Turner, Jenia, 'The Exclusionary Rule as a Symbol of the Rule of Law', (2014) 67 SMU Law Review, 821-833. [Turner, 2014]

\section{Contributions to Edited Volumes and Annotated Law}

Bachmaier Winter, Lorena, 'Spain: The Constitutional Court's Move from Categorical Exclusion to Limited Balancing', in: Thaman, Stephen C., ed., Exclusionary Rules in Comparative Law, New York 2013, 209-234. [Bachmaier Winter, 2013]

Borgers, Matthias J./Stevens, Lonneke, 'The Netherlands: Statutory Balancing and a Choice of Remedies', in: Stephen C. Thaman ed., Exclusionary Rules in Comparative Law, New York 2013, 183-207. [Borgers/Stevens in Thaman, 2013]

Lin, Yu-Hsiung et al., 'The Potential to Secure a Fair Tiral Through Evidence Exclusion: A Taiwanese Perspective', in: Gless, Sabine/Richter, Thomas (eds.), Do Exclusionary Rules Ensure a Fair Trial? A Comparative Perspective on Evidentiary Rules, Cham 2019, 131-161. [Lin et al., 2019]

Macula, Laura, 'The Potential to Secure a Fair Tiral Through Evidence Exclusion: A Swiss Perspective', in: Gless, Sabine/Richter, Thomas (eds.), Do Exclusionary Rules Ensure a Fair Trial? A Comparative Perspective on Evidentiary Rules, Cham 2019, 15-60. [Macula, 2019]

Porter, David/Kettles, Brent, 'The Significance of Police Misconduct in the Analysis of s. 8 Charter Breaches and the Exclusion of Evidence Under s. 24(2) in R. v. Grant, R. v. Harrison and R. v. Morelli', (2012) 58 Criminal Law Quarterly 510-530. [Porter/Kettles, 2012] 
Slobogin, Christopher, 'A Comparative Perspective on the Exclusionary Rule in Search and Seizure Cases', in: Ross, Jacqueline/Thaman, Stephen (eds.), Comparative Criminal Procedure, Cheltenham UK 2016, 280-307. [Slobogin, 2016]

Thaman, Stephen C., 'Balancing Truth Against Human Rights: A Theory of Modern Exclusionary Rules', in: Thaman, Stephen C., ed., Exclusionary Rules in Comparative Law, New York 2013, 403-446. [Thaman, 2013]

Triantafyllou, Georgios, 'Greece: From Statutory Nullities to A Categorical Statutory Exclusionary Rule', in: Thaman, Stephen C., ed., Exclusionary Rules in Comparative Law, New York 2013, 261-286. [Triantafyllou, 2013]

Turner, Jenia I., 'Regulating Interrogations and Excluding Confessions in the United States: Balancing Individual Rights and the Search for the Truth', in: Gless, Sabine/Richter, Thomas (eds.), Do Exclusionary Rules Ensure a Fair Trial? A Comparative Perspective on Evidentiary Rules, Cham 2019, 93-129. [Turner, 2019]

Turner, Jenia, 'Limits on the Search for Truth in Criminal Procedure: A Comparative View', in: Ross, Jacqueline/Thaman, Stephen (eds.), Comparative Criminal Procedure, Cheltenham UK 2016. [Turner, 2016]

Weigend, Thomas , 'The Potential to Secure a Fair Trial Through Evidence Exclusion: A German Perspective', in: Gless, Sabine/Richter, Thomas (eds.), Do Exclusionary Rules Ensure a Fair Trial? A Comparative Perspective on Evidentiary Rules, Cham 2019, 61-92. [Weigend, 2019] Weigend, Thomas, 'Throw It All Out? Judicial Discretion in Dealing with Procedural Faults', in: Caianiello, Michele/Hodgson, Jacqueline S. (eds.), Discretionary Criminal Justice in a Comparative Context, Durham, NC 2015, 185-205. [Weigend, 2015]

Jenia Iontcheva Turner is the Amy Abboud Ware Centennial Professor in Criminal Law at SMU Dedman School of Law, where she teaches criminal procedure, comparative criminal procedure, international criminal law, and international law.

Thomas Weigend taught criminal law and criminal procedure at the University of Cologne (Germany). He also served as a visiting professor at Peking University and the University of Political Science and Law in Beijing. He retired from teaching in 2016. His research is primarily dedicated to comparative criminal procedure and international criminal law.

Open Access This chapter is licensed under the terms of the Creative Commons Attribution 4.0 International License (http://creativecommons.org/licenses/by/4.0/), which permits use, sharing, adaptation, distribution and reproduction in any medium or format, as long as you give appropriate credit to the original author(s) and the source, provide a link to the Creative Commons license and indicate if changes were made.

The images or other third party material in this chapter are included in the chapter's Creative Commons license, unless indicated otherwise in a credit line to the material. If material is not included in the chapter's Creative Commons license and your intended use is not permitted by statutory regulation or exceeds the permitted use, you will need to obtain permission directly from the copyright holder. 